УДК 655.3.026.11:547.458:678

(ㄱ Р. А. Хохлова, к.т.н, доцент, Є. С. Вальков, магістрант, НТУУ «КПІ», Київ, Україна

\title{
ВЛАСТИВОСТІ ПРИРОДНИХ ПЛІВКОТВІРНИХ РЕЧОВИН ДЛЯ ВИГОТОВЛЕННЯ ЛАКІВ ТА ФАРБ, ЩО БІОРОЗКЛАДАЮТЬСЯ
}

Проведено дослідження характеристик природних поновлювальних плівкотвірних речовин як основи для розробки вітчизняних флексографічних друкарських фарб та лаків, що здатні до біорозкладання в природних умовах.

\section{Ключові слова: біодеградація; біополімер; фарба, що біорозкладається; флексографічний спосіб друку; кукурудзяний крохмаль.}

\section{Постановка проблеми}

Розширення асортименту товарів призводить до збільшення як назв, так і об'ємів паковань, для виготовлення яких можуть використовуватися папір, картон, гофрокартон, одношарові і багатошарові полімерні плівки та інші пакувальні матеріали. Водночас, вже тривалий час однією зі світових проблем є утилізація та переробка паковань, інертних до навколишнього середовища. В останнє десятиліття багато країн світу ввели обмеження і заборони на використання полімерної упаковки. Тепер, для виробництва безпечних пакетів, плівок і іншої пластикової продукції найбільш ефективним засобом визнано полімерні матеріали, що біорозкладаються в умовах зовнішнього середовища.

Біополімери для різного роду упаковки випускаються на основі природних поновлюваних речовин (наприклад, крохмаль, полімолочна кислота тощо) та синтетичних полімерів, яким за допомогою певних модифікацій надається здатність до біоруйнування, наприклад введенням оксо-добавки у склад традиційної полімерної плівки, яка й ініціює біорозкладання паковання. Такого роду полімери широко використовуються у пакувальній промисловості за кордоном. На вітчизняному поліграфічному ринку вони активно пропонуються фірмами «Полимер» (Україна), «Биопластик лтД» (Україна), «НовоПласт» (Україна), ТампоМеханіка (Росія), ЕвроБалт (Росія).

Якісний друк на різноманітних пористих та невсотувальних основах переважно здійснюється на машинах флексографічного друку. Саме завдяки друкарсько-технічним властивостям і технологічним характеристикам флексографічних фарб досягаються необхідні для багатьох паковань візуальні показники яскравості, насиченості кольору, глянцю; забезпе- 
чується стійкість до дії світла, хімічних речовин, фізико-механічних впливів заморожування, термозварювання тощо. Проте, однією із актуальних проблем пакувальної індустрії $€$ безпечність друкарських фарб по відношенню до запакованих продуктів, зокрема, харчових, та їх екологічність. Оскільки активізується процес використання біопластиків, то постає необхідність й у застосуванні друкарських фарб, що біорозкладаються, якими коректно було б проводити опорядження екологічно чистого паковання.

Якщо біопластики закордонного та й вітчизняного виробництва досить активно просуваються на український пакувальний ринок, то флексографічні друкарські фарби, що біорозкладаються, пропонуються на ринку лише закордонними фірмами-виробниками в надто обмеженій кількості і лише під індивідуальне замовлення, вітчизняні розробки таких матеріалів відсутні. Тому дослідження властивостей плівкотвірних речовин як основи для розробки рецептури флексографічних друкарських фарб, що біорозкладаються, із використанням вітчизняної поновлюваної сировини, є актуальною науково-прикладною проблемою, вирішення якої сприятиме удосконаленню виробничо-технологічних процесів виготовлення і оформлення паковань та їх екологічної утилізації.

\section{Аналіз попередніх досліджень}

На основі проведеного патентного пошуку, вивчення фа- хової періодичної літератури, здійснено аналіз стану і світових тенденцій розробки екологічночистих матеріалів, що біорозкладаються [1]. Так, двадцяте століття практично повністю ознаменовано дослідженням i розробкою таких матеріалів, але саме на останні тридцять років припадає інтенсифікація патентування, що підтверджує зацікавленість людства у збереженні планети для наступних поколінь. За останні двадцять років США $є$ ініціатором і, практично, провідним розробником таких матеріалів.

Також слід відмітити, що саме для флексографічного друку притаманне збільшення розробок, адже цей спосіб застосовується для нанесення інформації на ковбасні й сирні оболонки, соки у разових пакетиках тощо. Цікавим $€$ зосередження уваги на жирних кислотах як компонентах для біорозкладання у ґрунтах. Так, розробка індійського виробника EnNatura - фарба ClimaPrint, що повністю біорозкладається, на основі рослинної олії та запатентованої натуральної смоли, отриманої з касторової олії, яка $€$ органічним дезінфікуючим засобом. Хімічний склад фарби дозволяє ефективніше, дешевше та з меншими енергозатратами утилізувати відбитки, віддруковані нею, оскільки спрощує зазвичай складний процес відокремлення фарби від паперу для отримання чистої целюлози [2, 3].

Одним із найважливіших компонентів, що впливає на властивості флексографічних фарб, що біорозкладаються, - біополі- 
мер, що здатний деградувати під дією умов навколишнього середовища, може бути виготовлений із відновлювальної (в основному рослинної) сировини або ж 3 нафтохімічної за допомогою трьох основних способів [4]: частковою модифікацією природних полімерів (наприклад, крохмалю); отримання мономерів на біооснові хімічним шляхом або ферментацією з остаточною полімеризацією (наприклад, полілактонова кислота PLA); пряме виробництво полімерів в мікроорганізмах або генетичномодифікованих рослинних культурах (наприклад, полігідроксиалконоати - РНА).

Через необхідність доступності сировини із одночасним її здешевленням $€$ проблеми виробництва флексографічних друкарських фарб, що біорозкладаються, зокрема вітчизняних, на природній основі. В якості основи для таких фарб можуть використовуватися різного роду крохмалі рослинного походження (кукурудзяний, картопляний, рисовий тощо) та їх модифіковані різновиди, а також білки рослинного (соєвий) та тваринного (кісткові, казеїнові) походження, які виробляються в Україні.

\section{Мета роботи}

Мета роботи полягала у дослідженні фізико-хімічних характеристик природних поновлювальних плівкотвірних речовин як основи для розробки вітчизняних флексографічних друкарських фарб та лаків, що здатні до біорозкладання в природних умовах, із сировини власного виробництва.

\section{Результати проведених досліджень}

У відповідних умовах до технології використання готувалися водні розчини широкого асортименту природних полімерів, що виробляються на базі вітчизняної поновлювальної сировини, зокрема такі: казеїну, картопляного крохмалю, крохмалю кукурудзяного модифікованого у сухому стані (KKC), пшеничного білку, пшеничного ацетильованого крохмалю (ПАК), соєвого білку, пшеничного модифікованого крохмалю дікрохмаль фосфат (ПМК) Е1412, водорозчинної пасти кукурудзяного крохмалю (ККП).

Для флексографічного друку технологічно необхідним рівнем $\mathrm{pH}$ друкарських фарб $є$ значення 8,2-8,5, а в'язкість має бути в межах 18-24 с за В3-4. Саме тому проведені дослідження зміни в'язкості розчинів дослідних зразків природних біополімерів від температури, концентрації плівкоутворювачів, впливу концентрації нейтралізуючої речовини на $\mathrm{pH}$ розчинів, були поставлені на досягнення цих вимог.

Плівкоутворювач на основі крохмалю, як один 3 найбільш поширених природних вуглеводів, Є аморфним зернистим порошком білого кольору, нерозчинний у холодній воді. В гарячій воді набухає (розчиняється), у розчині йоду має синє забарвлення. У воді, при додаванні кислот (розбавленої $\mathrm{H}_{2} \mathrm{SO}_{4}$ тощо) як каталізатора, поступово гідролізується із зменшенням молекулярної маси 3 утворенням розчинного крохмалю, декстринів, глюкози - модифікація крохмалю. 
Приготування розчину крохмалю картопляного проводилося на водяній бані при температурі до $80{ }^{\circ} \mathrm{C}$ впродовж 45 хв. Крохмаль розчинявся та утворювалася гелеподібна маса. Досліджувалися розчини із концентрацією крохмалю 9-13\%, що відповідали в'язкості 60 с по В3-4, при рH 5,4-6,4 з метою визначення залежності їх в'язкості від концентрації крохмалю картопляного (рис. 1, крива 1) та впливу температури на в'язкість розчину (рис. 3, крива 1). Так, при мінімально допустимій концентрації картопляного крохмалю в розчині в межах $11 \%$, формується в'язкість 22 с, причому необхідна робоча в'язкість водного розчину, що має відповідати 18-24 с, забезпечується тільки при температурах близько $45{ }^{\circ} \mathrm{C}$. Одночасно збільшення концентрації сухого крохмалю призводило до згущення розчинів, що унеможливлювало визначати в'язкість, однак з часом в'язкість розчину знижувалася до 16 с й відслідковувалося розшарування окремих гелеподібних згустків та води. При зниженні концентрації крохмалю понад 10 \%, формуються ще більш нестабільні розчини.

Також через п'ять-сім діб на поверхні розчину з'являлася пліснява сірого кольору, що можна пояснити високим

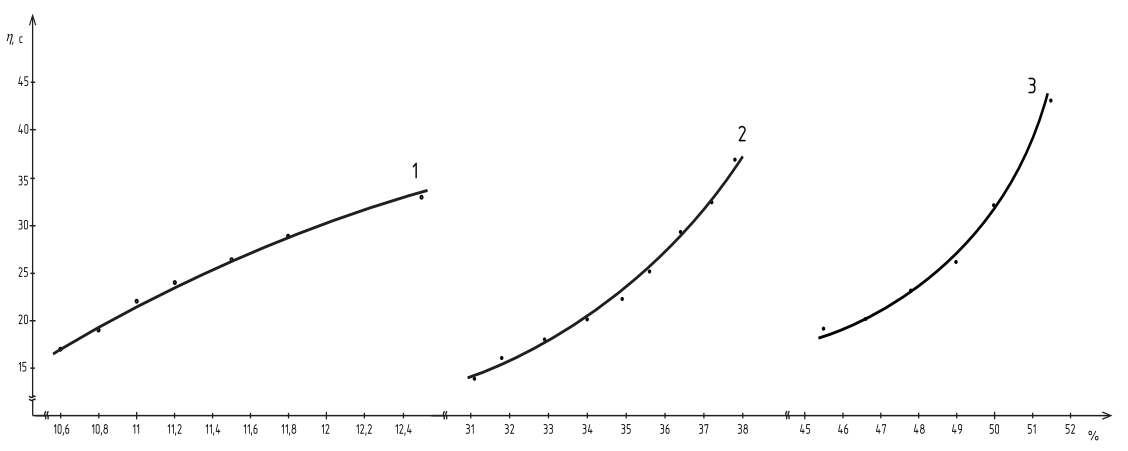

Рис. 1. Залежність в'язкості водних розчинів від концентрації плівкотвірних речовин: 1 - картопляний крохмаль, 2 - казеїн, 3 - кукурудзяний крохмаль паста (ККП)

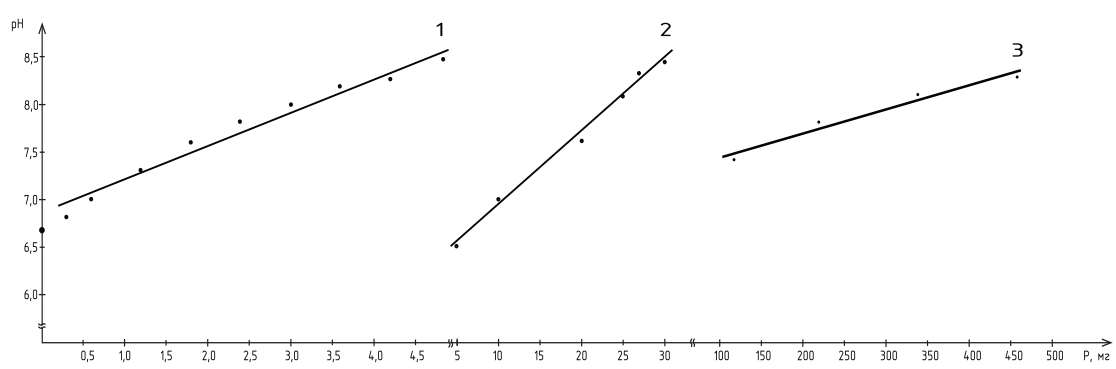

Рис. 2. Вплив концентрації триетаноламіну на рН водних розчинів плівкотвірних речовин: 1 - казеїн, 2 - кукурудзяний крохмаль сухий (ККС), 3 - кукурудзяний крохмаль паста (ККП) 
вмістом гідроксильних груп, які стимулюють передчасне розкладання біополімеру. Для перешкоджання появи плісняви застосовували етиловий спирт, як антисептик, у встановленій дослідним шляхом кількості $5 \%$. Причому при збільшенні вмісту спирту утворювався білий осад, що свідчить про несумісність спирту та водного розчину картопляного крохмалю.

При первинному додаванні казеїну у воду спостерігалося його погане розчинення та формувалися кислі розчини. Нагрівання покращувало розчинення казеїну у воді, однак й підвищувало рН розчину (рис. 1, крива 2; рис. 2, крива 1, рис. 3, крива 2). Характерним $€$ й те, що розчинений у воді казеїн формував розчини коричневого кольору, які були не стабільні у часі: на їх поверхні формувалася густа плівка, а на дні рихлий осад. Через сім-десять діб на поверхні утворювалася пліснява, для перешкоджання утворення якої було використано етиловий спирт як антисептик. При його введені у незначній кількості пліснява відсутня не один місяць.

Виходячи 3 того, що водний розчин казеїну має коричневий колір - це позбавляє можливості виготовляти фарби білого, жовтого, червоного кольору тощо, оскільки це буде змінювати колір та відтінок фарби. Також через суттєве розшарування розчинів, подальша робота із казеїном була призупинена.

Приготування розчину кукурудзяного крохмалю модифікованого (ККС) при концентрації сухої речовини в межах 2,6-5 \% відбувалося при вихідному зна-

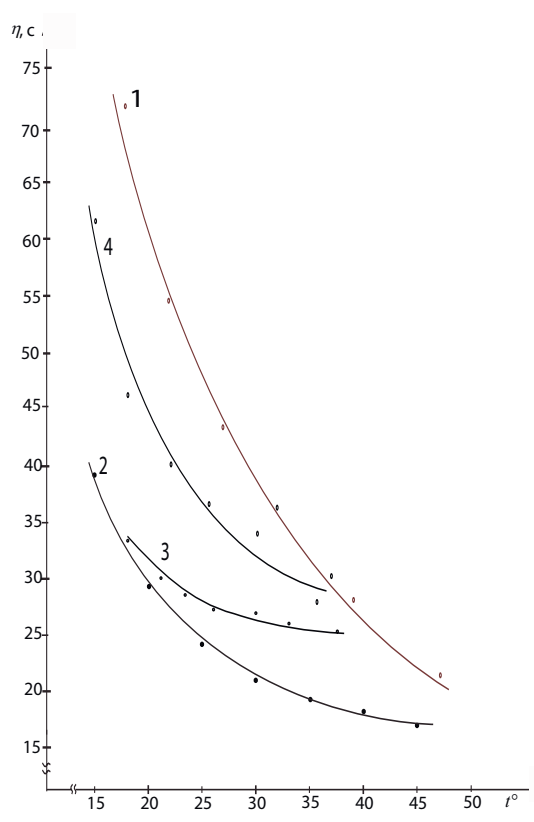

Рис. 3. Вплив температури на в'язкість водних розчинів плівкотвірних речовин: 1 - картопляний крохмаль; 2 - казеїн; 3 - кукурудзяний крохмаль сухий (ККС); 4 - кукурудзяний крохмаль паста (ККП)

ченні рН 6,3 та в'язкості 35 с за температури $18{ }^{\circ} \mathrm{C}$ (рис. 3, крива 3). Після розчинення крохмалю розчин структурувався в масі 3 утворенням водяних прошарків. Було встановлено, що 3 часом (понад десять діб) в'язкість розчину ККС зменшується з 38 с до 12 с за ВЗ-4. Зростання $\mathrm{pH}$ розчину до значення 8,5 було досягнуто при додаванні ТЕА в межах 28 г (рис. 2, крива 2). Таким чином встановлені мала концентрація кукурудзяного крохмалю, що забезпечує в'язкість до 40 с, розшарування та нестабільність розчину не дають можливості застосування його при виготовленні флексографічної фарби, яка біорозкладається. 
На основі сухого порошку пшеничного білку, готували водні розчини 18-24 \% концентрації при різних ступенях $\mathrm{pH}$ $6,4-8,2$ та нагріванні до $35{ }^{\circ} \mathrm{C}$. Після введення у воду сухого порошку та при перемішуванні, однорідної структури було досягти неможливо - утворювалися окремі згустки клейстеру. При подальшому розбавленні водою формувалися розчини білого кольору, які при зберіганні розшаровувалися із виокремленням білого осаду. За час проведення досліджень (понад тиждень) грибків на поверхні розчинів не було виявлено. Зважаючи на вимоги до водних розчинів, подальша робота із пшеничним білком призупинена.

Як плівкотвірну речовину природного походження було досліджено соєвий білок, що одержується після набухання зерен сої у воді шляхом термічної обробки в кислому середовищі. Отримана густа маса розбавлялася водою до рідкотекучої маси. I в кислому середовищі, і в лужному, після додавання нейтралізуючої основи триетаноламіну до рH 8,8 та нагріванні до $85^{\circ} \mathrm{C}$, соєвий білок не розчинявся, тому неможливо було досягти рідкого однорідного клейкого розчину. Через сімдесять діб на поверхні розчину формувалася пліснява, структура розшаровувалася. Враховуючи вказані недоліки, подальшу роботу із соєвим білком було призупинено.

Дослідження фізико-хімічних властивостей пшеничного модифікованого крохмалю дікрох- маль фосфат (ПМК) Е1412 починалося із приготування водного розчину при концентрації ПМК 9 \% з наступним нагріванням до $60{ }^{\circ} \mathrm{C}$. Після охолодження при $18{ }^{\circ} \mathrm{C}$ в'язкість розчину становила 30-32 с. Після перемішування вручну у розчині залишалися невеликі згустки. Вихідний рівень $\mathrm{pH}$ був в межах 7,65 одиниць, після додавання нейтралізуючої основи ТЕА було зафіксовано рН 8,55. Після зберігання розчину понад сім діб він структурувався, розшаровувався, тому перевірити в'язкість було неможливо. Після розбавлення водою та доведення концентрації ПМК до 5,6 \%, розчин у часі втрачав свою в'язкість та був нестабільним. Виходячи 3 того, що концентрація ПМК невелика, в'язкість розчину з часом знижувалася та була нестабільна, подальші дослідження не проводилися.

Також досліджено було пшеничний ацетильований крохмаль (ПАК), водний розчин якого готували при концентрації ПАК в межах $4 \%$. При температурі розчину $16{ }^{\circ} \mathrm{C}$, розчин був надто густий, за віскозиметром В3-4 перевірити в'язкість було неможливо. Зменшення концентрації ПАК шляхом додавання води недоцільно, оскільки за технічними вимогами, концентрація плівкотвірних речовин у розчині має бути не мене $10 \%$. Саме тому подальші дослідження ПАК не проводили.

Водорозчинна паста кукурудзяного крохмалю (ККП) відрізняється концентрацією сухого крохмалю, вмістом багатоатомного спирту, консерванту 
та антисептика. Встановлено, що максимально наближені результати до встановлених вимог дає саме розчин кукурудзяного крохмалю ККП при вмісті його у вихідній рецептурі 48-50 \%, що формує в'язкість розчину до 30 с при температурі до $25^{\circ} \mathrm{C}$ (рис. 1, крива 3). Технологічно необхідний рівень рН розчину, який відповідає вимогам до флексофарби, від 8,2 до 8,5 може бути досягнено за умов введення триетаноламіну в кількості 460-500 мг на 100 г розчину (рис. 2, крива 2).

\section{Висновки}

1. Властивості природних плівкотвірних речовин кукурудзяного крохмалю, казеїну виявили придатність для застосування їх у біорозчинних лакофарбових матеріалах.

2. Подальші дослідження по встановленню оптимальних параметрів водних розчинів природних полімерів для виготовлення екологічночистих флексографічних друкарських фарб та лаків, що біорозкладаються, доцільно продовжити з використанням пасти кукурудзяного крохмалю ККП.

\section{Список використаної літератури}

1. Хохлова Р. А. Тенденції розвитку безпечних флексографічних фарб для друковування на пакованнях / Р. А. Хохлова, А. І. Степанець // Упаковка. - 2012. - № 3. - С. 32-37.

2. Сдобникова О. А. Биоразлагаемая упаковка - путь к улучшению экологии // Ресурс доступа : http://www.milkbranch.ru/publ/view/515.html.

3. Lo Ch. Supporting eco-friendly packaging : green inks// Packaging-gateway.com. - 2012 // Access mode : http://www.packaging-gateway.com/features/featureeco-friendly-ink-uv-flexo-biodegradable-ink.

4. Замотаев П. В. Полимеры, разрушающиеся под действием природных факторов / П. В. Замотаев // Упаковка. - 1999. - № 4. - С. 34-37.

\section{References}

1. Khokhlova R. A. Tendentsii rozvytku bezpechnykh fleksohrafichnykh farb dlia drukovuvannia na pakovanniakh / R. A. Khokhlova, A. I. Stepanets // Upakovka. - 2012. - № 3. - S. 32-37.

2. Sdobnikova O. A. Biorazlagaemaja upakovka - put' $k$ uluchsheniju jekologii // Resurs dostupa : http://www.milkbranch.ru/publ/view/515.html.

3. Lo Ch. Supporting eco-friendly packaging : green inks// Packaging-gateway.com. - 2012 // Access mode : http://www.packaging-gateway.com/features/featureeco-friendly-ink-uv-flexo-biodegradable-ink.

4. Zamotaev P. V. Polimery, razrushajushhiesja pod dejstviem prirodnyh faktorov / P. V. Zamotaev // Upakovka. - 1999. - № 4. - S. 34-37.

Проведено исследование характеристик природных возобновляемых пленкообразующих веществ как основы для разработки отечественных флексографских печатных красок и лаков, способных к биоразложению в естественных условиях. 
Ключевые слова: биодеградация; биополимер; биоразлагаемая краска; флексографический способ печати; кукурузный крахмал.

The investigation of the characteristics of natural renewable binding agents as a basis for developing flexographic printing inks and varnishes, which are capable of biodegradation under natural conditions.

Keywords: biodegradation; biopolymer; biodegradable ink; flexographic printing process; corn starch.

Надійшла до редакції 17.03.14 